\title{
THE CASE OF THE TRANS-MISSOURI FREIGHT ASSOCIATION.
}

The importance of the decision of a court of justice may depend either upon the principle involved in the decision, or upon the practical effect of the decision as affecting human life, liberty or property interests. The recent decision of the Supreme Court of the United States is of wide spread importance, not only by reason of the principle of law involved by the court, but because the enunciation thereof may seriously affect the value of securities of railways in the United States. This decision was rendered in the case of the TransMissouri Freight Association, decided on March 22, 1897 . In view of its importance, and of the general.apprehension that it has caused, it may be of some value to consider carefully the decision, not only as to that which was actually decided with reference to the facts of the particular case, but also as to the principle of law, which will determine similar cases as they may arise in the future. If the principle itself be of importance, a fortiori, is it so when declared by a court, the breadth of whose jurisdiction and whose personnel entiţle any decision thereof to the utmost respect.

The facts in the case are as follows: By articles of agreement, dated March 15, 1889, fifteen railroad companies, competitors for the freight traffic in that part of the United States between the Mississippi and Missouri Rivers and the Pacific Ocean, formed an association called the Trans-Missouri Freight Association. The articles of agreement provided, inter alia, that the parties thereto would establish and maintain such rates, rules, and regulations on freight traffic between competitive points as a committee of their choosing should recommend as reasonable; that these rates, rules, and regulations should be public; that there should be monthly meetings of the association composed of one representative from each railroad company; that each company should give five days' notice before each monthly meeting of every reduction of rates or deviation from the rules it should propose to make; that it 
would advise with the representatives of the other members at the meeting relative to the proposed modification; that it would submit the question of its proposed action to a vote at that meeting, and if the proposition should be voted down, that it would then give ten days' notice that it would make the modification, notwithstanding the vote, before it should put the proposed change in effect, and that no member would falsely bill any freight, or bill any freight at a wrong classifica. tion; and that any member could withdraw from the association on a notice of thirty days. The articles further provided that in case any of the managers of the lines, parties to the agreement, should fail to agree upon any question arising thereunder, that then the question should be referred to an arbitration board, which should consist of three members of the executive board of the Inter-State Commerce Railway Association, provided, however, that in case of arbitration in which the members of the association only were interested, that they might by unanimous vote substitute a special board. In other words, it was in substance, "an agreement between the corporations by which a uniform classification of freight is obtained, by which the secret undercutting of rates is sought to be avoided, and the rates as stated in the published rate sheets, and which, as a general rule, are required by law to be filled with the Inter-State Commerce Commission or secured against arbitrary and sudden changes." 1

On January 6, I892, the United States Attorney for the District of Kansas, under the direction of the AttorneyGeneral, filed a bill in equity in the Circuit Court of the United States of the District of Kansas on behalf of the United States against this Association, and the railway companies which constituted the same. The bill, after reciting the articles of agreement in question, alleged, inter alia, that the defendant railroad companies were common carriers, and owning independent and competitive lines of railroads in that part of the United States west of the Mississippi and Missouri Rivers; that they were engaged in transporting freight among the states and to and from foreign nations; that the defendants

1 Per White, J., in his dissenting opinion. 
not being content with the rates of freight that they were receiving, intending oppressively to augment these rates so as to counteract the effect of free competition upon them, and establish and maintain arbitary rates, thus procuring large sums of money from the people engaged in inter-state commerce in the aforesaid territory; that under the agreement rules, regulations, and rates for carrying freight oyer the railroads of the defendant companies were fixed by the association, and have since been maintained by them; that since that date these railroad companies have declined and refused at all times to fix or give rates for the carriage of freight based upon the cost of constructing and maintaining their seyeral lines of railroads and the cost of carrying freight over the same, and such other elements as should be considered in establishing tariff rates on each particular road; and that the people engaged in inter-state. commerce have been compelled to pay the arbitrary rates of freight and submit to the arbitrary rules and regulations established and maintained by the association under the agreement, and have been and are deprived of the benefit that might be expected to flow from free competition between the several lines of railroads of the defendant companies, and that in this way the defendant companies have continued, in restraint of trade and commerce, among the states, and have attempted to monopolize and have monopolized a part of this commerce, in violation of the provisions of the Act of Congress, July 2, I 890. ${ }^{1}$ The bill further prayed a decree dissolving the association, and asked for an injunction restraining the several defendants from carrying out the terms of the said agreement, or from agreeing to prevent each and any of them from carrying freight at such rates as shall be voluntarily fixed by the officers and agents of each of said roads, acting independently in its own behalf. ${ }^{2}$

\footnotetext{
126 Stat. at Large, 209, Ch. 647.

2 The title and sections of that act material to this question are as follows:

AN ACr to protect trade and commerce against unlawful restraints and monopolies.

Sec. I. Every contract, combination in the form of trust or otherwise,
} 
The answer of the defendants admitted that they werecommon carriers, that they owned independent and competing lines of railroads, but denied that they owned the only through lines of railroads in the aforesaid territory; it also admitted that they had entered into the agreement in question, that rules, regulations and rates of freight have been fixed and changed by the association formed, which rates have been com-plied with and maintained. They denied that they intended, in connection with the formation of the association or otherwise, to unjustly or oppressively augment such rates, or to counteract the effect of free competition on prices, or facilities of transportation; they deny that they had any intention by the formation of the association to monopolize or attempt tomonopolize the freight traftic affected by it, and deny that the agreement has had such effect. Pending the decision thereof, the association was voluntarily dissolved. The cause having been heard on bill and answer on November 28,1892 . JudgeRiner, the District Judge, ${ }^{1}$ dismissed the bill for two reasons, (I) that the agreement in question was not a contract in restraint of trade within the meaning of that phrase as used in the Act of July 2, 1890, as the restraint provided for in the agreement was a reasonable one, in that it was necessary tothe protection to the parties to this agreement and was not prejudicial to the public interests, and neither was it a monopoly nor an attempt at one; and (2) that common carriers were not within the provisions of the Act of July 2, 1890. Their

or conspiracy in restraint of trade or commerce among the several states,. or with foreign nations, is hereby declared to be illegal. Every person who shall make any snch contract or engage in any such combination or conspiracy shall be deemed guilty of a misdemeanor, and on conviction thereof shall be punished by a fine not exceeding five thousand dollars, or by imprisonment not exceeding one year, or by both said punishments. in the discretion of the court.

Sec. 2. Every person who shall monopolize or attempt to monopolize, or combine or conspire with any other person or persons to monopolize any part of the trade or commerce among the several states or with foreign nations, shall be deemed guilty of a misdemeanor, and on conviction thereof shall be punished by fine not exceeding five thousand dollars, or by imprisonment not exceeding one year, or by both said punishments in the discretion of the court.

${ }^{1} 53$ Fed. Rep. 440. 
duties and liabilities being solely governed by the provisions of the "Inter-State Commerce Act." Upon an appeal to the Circuit Court of Appeals of the Eighth Circuit, that court of two to one, on October 2, I 893, ${ }^{2}$ by a vote affirmed the decision of the District Judge, for the first reason as given by him and declining to decide whether common carriers were subject to the Act of July 2, 1890. An appeal was then taken to the Supreme Court of the United States, who, by a vote of five to four, reversed the decisions of the Circuit Court of Appeals and of the District Court. Mr. Justice Peckham delivering the opinion of the court on behalf of himself, and Justices, Brewer, Brown, Fuller, and Harlan, while Mr. Justice White delivered a dissenting opinion in which Justices Field, Gray, and Shiras concurred.

The importance of the decision would seem to justify the detail in which the facts have been stated. Two substantial questions were presented to the court, both of which must be and were answered in the affirmative in order to maintain the bill :

(1) Does the Act of July 2, 189o, embrace within its provisions common carriers by railroads, and if so (2), does the agreement set forth in the bill violate any provisions of that Act? In this article it is proposed to only consider briefly the facts in the case and the opinion of the court in answering the second question in the affirmative. An examination of the Act of July 2, r89o, will show that it is aimed at two evils, (a) contracts in restraint of trade, and (b) monopolies. Mr. Justice Peckham, in his opinion, does not pretend that the agreement in question constituted a monopoly or an attempt at one, but bases the decision of the court solely upon the ground that the articles of agreement which gave birth to the TransMissouri Freight Association constituted a contract in restraint of trade, as that phrase is used in the Act of July 2, I 890, and that, therefore, the execution thereof was in violation of the terms of that act.

Under this view of the statute it is of importance to deter-

1 Act of Congress, Feb. 4, 1887 .

${ }^{2} 5^{8}$ Fed. Rep. 58 . 
mine what is a "contract in restraint of trade" as shown by the historical development of this branch of the law.

It is submitted that the history of its development is thehistory of a judicial declaration of public policy, undoubtedly sound at the time it was made, of its continued declaration by the courts, together with a grudging recognition that the severity of the common law rule should be changed to meet. the changes in industrial conditions, and that as the reason for the rule became limited in its application so correspondingly should the prohibited class be narrowed. At the time when this doctrine was first enunciated by the courts (I4I 5), combinations of capital such as exist to day were of course unknown. The protection of the individual was the ratio decidendi, indirectly of course, the interests of the public were considered for "especially in young men, who ought in their youth (which is the seed time) to have lawful sciences and trades which are profitable to the commonwealth, and whereof they might reap. the fruit in their old age, for idle in youth, poor in age, and therefore the common law abhors all monopolies which prohibit any from working in any lawful trade." 1

The commercial activity of England: the fact that no longer could a man only lawfully exercise a trade to which he had been duly apprenticed and admitted, soon demonstrated to the English courts that such, a priori, declarations of public policy as given above were not, ipso facto, sound and that a practical enforcement thereof would foster the very evil that the doctrine was meant to prevent, and so the courts said,. " if the restraint be partial with respect to space, and reasonable, we will enforce it, ${ }^{2}$ and we will consider it reasonable if two elements be present, first, necessity of such protection to the promisee, and second, that such protection shall not be so large as to interfere with the interests of the public. ${ }^{3}$ and finally the courts declared that the fact that the restraint was partial as to space was no longer a pre-requisite to its validity.

IIpswich Taylor's Case, ir Cooke, 540.

2 I itchell $v$. Reynolds, I P. Wms. I8I.

${ }^{3}$ Homer $v$. Graves, 7 Bing. 735 .

'Jones $v$. Lees, I Man. \& Gr. I95; Ronsillon $v$. Ronsillon, L. R. 14 Ch. D. 35I ; Mills v. Dunham, I Ch. 576; Nordenfelt $v$. Nordenfelt Guns. and Ammunition Co., 94 App. C. 535 . 
The development, in the United States, of this branch of the law can hardly be said to have kept pace with the industrial development of the country. Our courts have forgotten that "Public policy is an unruly horse, and once you get astride of him you never know where he will carry you," (per Mr. Justice Burrough in Richardson y. Mellissh, 2 Bing. 229) and have ridden that horse at every opportunity. At one time it was thought that "with regard to domestic interests each state is a separate community, and it is by no means the same thing to the people of a state whether an individual carries on its trade within or without its borders," and that therefore a restriction co-extensive in point of space with the boundaries of a state was contrary to the public policy of that state, even though the individual so restrained could exercise his trade anywhere else, and this extremely liberal view prevails to-day in Michigan.. Fortunately, however, as it came to be understood that the states were not separate communities with respect to their business interests, a broader view prevailed, and even though a restraint be ca-extensive with the state, yet if it be reasonable the court will enforce it. If, however, the restraint be co-extensive with the United States, the current of authority would seem to hold it invalid, irrespective of the question of reasonableness, though the courts of New York, Missouri, and Minnesota, follow the modern English rule. ${ }^{2}$

From this cursory sketch of the development of the law, it can be seen that the law as to contracts of this character is founded solely upon public policy, and as public policy changes, so must the law change, and that therefore the question as to whether or not a given contract is in restraint of trade is a question which depends upon what constitutes public policy "at the time of the contract's enforcement."

- But, as is stated by Mr. Justice Peckham in his opinion, the plain words of the Act of 1890 are, "Every contract . . . in restraint of trade . . is hereby declared to be illegal," and . the term includes all kinds of those contracts which in fact restrain, or may restrain, trade.

1 Western Wooden Ware Association $\dot{v}$. Starkey, 84 Mich. 76.

${ }^{2}$ See AM. LAW REgISTER AND REVIEW, January, I893, p. 50. 
What, then, is the technical meaning of the phrase, "contracts in restraint of trade." Does it include all contracts, though they, in some measure, legally restrain trade, or is its meaning restricted to contracts whose restraint is unreasonable, and therefore invalid?

It must be admitted that in the cases there can be found dicta from numerous Judges who use the phrase, "contracts in restraint of trade," as having a generic meaning, irrespective of the question as to the validity of the restraint.

But, on the other hand, what is the historical origin of the rule? How was it that contracts of this character fell under the ban of the common law? It was not because they restrained trade in any way at all, but becaise they restrained it in such a manner as to be contrary to public policy.

It may be perfectly true that Dyer's Case, ${ }^{1}$ and Colgate v. Batchelor, ${ }^{2}$ decided that any restraint was invalid, but that was because in those cases the courts declared that at that time any restraint on trade was contrary to public policy.

As then public policy is the determining factor if the restraint of the contract is not contrary to public policy, then it is not invalid, and is not a " contract in restraint of trade." That this definition is sound can be seen from an examination of some of the recent decisions on this subject. In Brewing Association v. Houck, ${ }^{3}$ a brewing association had entered into a contract with certain parsons to furnish beer to them and not to any other person in a given city for the period of one year. In delivering the opinion of the court, James, C. J., said (page 696): "We think that the contract entered into by the defendants and their associates was not objectionable as being in restraint of trade at common law."

In Davis v. Brown," Guffy, J., said: "A contract on the part of appellant to not engage in the buggy business in ' $O$ ' county was not void as being in restraint of trade."

In B.E.V.R.R. Co. v. N.V.R.R. Co., ${ }^{5}$ Dean, J., in de-

${ }^{2}$ I4I5, Y. B. 2 H. 5, p1. 22.

${ }^{2}$ Cro. Eliz. 872.

${ }^{3}$ I894, 27 S. W. 692, 88 Tex. 184 .

4 I 895,32 S. W. 614 .

${ }^{5}$ I895, I7I Pa. St. 284-299. 
livering the opinion of the court, sustaining an agreement by which a railroad company contributed money for the development of ore land, the owner thereof agreeing to give to the railroad company all traffic to and from the land and the furnace thereon, said: "It is not in restraint of trade, for the express purpose, and necessary effect are to increase both trade and population."

In Matthew v. Associated Press of New York, ${ }^{1}$ the question before the court was as to the validity of a by-law of a new association, which in terms prohibited the members from receiving or furnishing "the regular news dispatches of any other news association covering a like territory and organized for a like purpose. Mr. Justice Peckham (then a judge of the Court of Appeals of New York), for the court, said (p. 340): "The latest decisions of courts in this country and in England show a strong tendency to very greatly circumscribe and narrow the doctrine of avoiding contracts in restraint of trade. The courts do not go to the length of saying that contracts which they now would say are in restraint of trade are, nevertheless, valid contracts, and to be enforced; they do, however, now hold many contracts not open to the objection that they are in restraint of trade, which a few years back would have been avoided on that sole ground, both here and in England ... . So that, when we agree that a by-law which is in restraint of trade is void, we are still brought back to the question, What is a restraint of trade in the modern definition of that term?

The authority to make by-laws must also be limited by the scope and purpose of the association. I think this by-law is thus limited, and that is not in restraint of trade, as the courts now interpret that phrase."

So, also, the House of Lords, in Nordenfelt v. Nordenfelt Guns and Ammunition Company, ${ }^{2}$ held valid an agreement under which a patentee and manufacturer of guns and ammunition for purposes of war, covenanted with a company to which his patents and business had been transferred, that he

1136 N. Y. 333.

${ }^{2} 94$ Ap. Cases, 535 . 
would not for twenty-five years' engage, either directly or indirectly, in the business of a manufacturer of guns and amunition, not because the agreement in question was in reasonable restraint of trade, and therefore valid, but because its reasonableness prevented it from being in restraint of trade.

No one can doubt that the agreement in every one of these cases in some measure restrained trade; but as the opinions quoted show that they were not technical contracts in restraint of trade, they could only become so when their restraint was unreasonable.

Is not also the title of the act in harmony with this view? It reads: "An act to protect trade and commerce against unlawful restraints and monoplies;" not an act to protect trade against any restraint whatsoever, but an act to protect trade against unlawful restraints-that is, unreasonable onesand it is submitted that the title of the act can be used as an aid to the construction of the body of the statute, not to contradict its plain terms, but as a help to determine the doubtful ones. ${ }^{1}$

Indeed, Mr. Justice Peckham admits (page $22^{2}$ ) that "A contract which is the mere accompaniment of the sale of property, and thus entered into for the purpose of enhancing the price at which the vendor sells it, which in effect is collateral to such sale, and where the main purpose of the whole contract is accomplished by such sale, might not be included, within the letter or spirit of the statute in question." Why should a contract which is collateral to a sale be exempted from the operation of the statute while a contract not collateral to a sale be subject thereto?

There is nothing in the statute expressly or implicitly which would support such a construction. It would seem as if the learned judge was constructing a means by which the court might in future escape from the consequences of a strict adherence to his views.

1 U. S. v. Palmer, 3 Wheat. 610, 63I ; Coosaw Mining Co. v. S. C., I 44 U. S. 550,563 .

${ }^{2}$ The paging refers to Senate Document No. 12, Fifty-fifth Congress, first session, which contains the opinions filed in the case. 
But, objects Mr. Justice Peckham, in view of the difficulty of determining what is reasonable, to say that the reasonableness of such an agreement as this is the the test of its validity " is substantially to leave the question of reasonableness to the companies themselves." 1 This is a difficulty which the courts have always been able to overcome in the four hundred years in which such questions have come before them. They have always solved the problem whether it was before them as .an individual restraint or in the form of a combination of capital to control the production or sale of a particular article. Indeed, that very court, of which Mr. Justice Peckhan is an honored member, has decided that the question as to the reasonableness of railway rates is a judicial and not a legislative one. ${ }^{2}$ Even if the rules were likewise this association did not or could not fix a particular rate and compel its members to abide thereby.

Assuming, then, that the invalidity of the agreement depends upon its unreasonableness, are the provisions of the agreement in question unreasonable; that is, are they contrary to the interests of the public, and in deciding this question, the burden of proof is upon the one who asserts its invalidity. ${ }^{3}$

But, says Mr. Justice Peckham, the business which the railroads do, is " of such a public nature that it may well be doubted, to say the least, whether any contract which imposes any restraint upon its business would not be prejudicial to the public interest." Quoting in support thereof Fuller, C. J., in Gibbs v. Baltimore Gas Company, I30 U. S. 596 , as to the distinction between the rules governing business of a public and private nature. Now it is perfectly true that public policy varies in this respect, but it is submitted that it is a difference which is not ipso facto determined by the character of the business. Another element must be considered, viz: the transaction itself, which is said to be in contravention of public policy.

It is believed that there is no authority other than loose

1 Page 24.

2 1890, C. M. \& St. P. Ry. Co. v. M4innesota, I34 U. S. ; I894, Reagan च. The Farmers' Loan \& Trust Company, I54 U. S. 362.

${ }^{3}$ Mr. Justice Chitty in Mills $v$. Dunham, 9r, Ch. C. A. 576.

' Page 24. 
dicta, for the proposition that business of a public nature may be of such a character that any restraint whatsoever is incompatible with the interests of the public, irrespective of the nature thereof.

Examine the cases cited by Chief Justice Fuller. In Transportation Company v. Pipe Line Company, 22 West Va. 600, a grant of an exclusive right-of-way over a tract of land for an oil-pipe line was held void. Now a careful perusal of the opinion of the court (especially page 625) will show that the basis of the decision of the court was that the people of West Virginia had, by various statutes, emphatically declared that it was the public policy of that State that the business of railroading, telegraphing, and transportation of oil by pipes, should be carried on at any place that a corporation chartered for that purpose might choose.

In other words, the agreement in question was illegal, because contrary to public policy, and it was contrary to public policy, because the effect thereof which was to prevent corporations chartered for a public purpose, and a purpose in the performance of which the public had a peculiar interest, from the performance of their corporate duties.

In The Western Union Telegraph Company v. The American Union Telegraph Company, the court held that: An agreement by a railroad company granting to a telegraph company the exclusive use and occupation of its right-of-way, was void because the means of inter-communication should not be monopolized, thus crippling competitors, and enabling one company to fix its tariff of rates at a maximum, governed alone by the necessities of its patrons.

So, in the Chicago Gas Light and Coke Company v. The Peoples' Company, 121 Ill. 530, where two Gas Companies had divided the City of Chicago, and agreed not to compete within each other's territory, the agreement was held bad, as tending to create a monopoly, and as an agreement not to perform the public duties for which the companies were chartered.

Again, where two railroads enter into an agreement not to ${ }^{1} 65 \mathrm{Ga} .160$. 
extend their roads, the agreement is void as a renunciation of their corporate duties; ${ }^{1}$ but on the other hand traffic arrangements for through transportation, i. e., arrangements for through tickets over connecting routes, are perfectly valid, and they may also provide for the division of fares based upon mileage. ${ }^{2}$

Also a railroad company may legally give another transportation company a monopoly of the handling of the business of the railroad. ${ }^{3}$

As briefly summing up the principle of these cases, it may be said that there is no business, whatever be the public interest therein, that any restraint thereon is, ipso facto, void, but, if the effect of the restraint be to form a monopoly of such business, or to prevent a public corporation from the performance of its chartered functions, then, the agreement is void.

The mere fact, therefore, that the business which was affected by the restraint, of the Trans-Missouri agreement was a business in which the public had a peculiar interest did not, ipso facto, render any restraint thereon invalid; nor did the agreement, on the other hand, violate in any manner the public policy of the United States as expressed in its statutes, or as -declared by its courts.

The distinguishing characteristic of the Trans-Missouri agreement was the attempt to prevent thereby the secret undercutting of rates as published, and also to secure the same against sudden and arbitrary changes. There was no attempt to maintain rates at an agreed figure, if any party to the agreement gave public notice of an intention to adopt some other rate.

In considering the question as to whether or not the agreement under consideration is contrary to the public interests, it

${ }^{1}$ H. \& N. W. R. R. Co. v. N. Y. \& N. H. R. R. Co., 3 Rob. 4 II ; State .v. H. \& N. H. R. R. Co., 29 Conn. 538 ; D. \& N. O. R. Co. v. N. A. T. \& S. F. Co., 15 Fed. Rep. $65^{\circ}$.

${ }^{2}$ H. \& N. H. R. R. Co. v. N. Y., N. H. \& H. R. R. Co., 3 Robb, $4 \mathrm{II}$; R. R. v. Ry. Co., Ig N. S. Eq. Ir3; 20 N. J. Eq. 542 ; Stuart v. E. \& W. Transportation Co., I7 Minn. 372 ; Elkins v. R. R. Co., 36 N. J. Eq. 246.

${ }^{3}$ Richmond v. R. R. Co., 22 Iowa IgI ; Ferry Co. v. R. R. Co., 73 Mo. .39r ; R. R. Co. v. R. R. Co., IIo U. S. 667 ; R. R. Co. v. Pullman .Southern Car Company, I39 U. S. 79. 
is submitted that we must not assume, a priori, that free and unrestricted competition of every description is, ipso facto, beneficial to the public at large. "It is a mistaken notion," said Vice-Chancellor Wood, "that the public is benefited by pitting two railway companies against each other till one is ruined; the result being at last to raise the fares to the highest possible standard." 1 But it must be admitted that the maxim as to free competition has been as prominent and as obtrusive in the minds of certain judges in their application of this branch of the law as King Charles' head was in Mr. Dick's literary efforts. Such was the ratio decidendi in Hooker v. Vandewater, 4 Denb, 349; Stanton v. Allen, 5 Dejoo, 434; Morris Run Coal Co. v. Barclay Coal Co., 68 Pa. St. I73; and G. \& P. Ry. Co. v. The Sp. Ry. Co., 4 I La. Ann. 970.

As a matter of fact, such a maxim has no part in modern political economy, and should have no part in modern jurisprudence. Have we not seen and heard enough of the benefits of free competition? Where is the benefit to the public in a rate war which reduces rates to a point insufficient to pay the operating expenses and fixed charges of a railroad and forces the road into a receivership? It is not urged that the railroads should be allowed to combine to charge excessive rates; but there is an adequate remedy for this in the machinery of the Inter-State Commerce Commission, and it is believed that the interests of the public are secured by such an agreement as that of the Trans-Missouri Freight Association.

There was nothing in it which sought to oppress the public. There was no agreement to maintain rates; in fact a means was especially provided by which any party to the agreement could lower its rate when it wished to. It was denied in the defendants' answer that they intended to unjustly augment those rates or counteract the effect of free competition, and as the cause was heard on bill and answer, the truth of the facts averred in the latter was undisputed. Surely there is nothing in such an agreement which is contrary to public interests. In fact it is in furtherance thereof. A somewhat similar agreement came for determination before the Supreme Court of New

${ }^{1}$ Hare v. I. \& N. R. Co., 2 J \& H. Ch. Rep. 80, 103. 
Hampshire and was unhesitatingly upheld. ${ }^{1} \quad$ No better statement of the fallacy of unrestricted competition can be found than the opinion of Blodgett, J., in that case. He says, inter alia, "For the lessons of experience, as well as the deductions of reason, amply demonstrate that the public interest is not subserved by competition which reduces the rates of transportation below the standard of fair compensation; and the theory which formerly obtained that the public is benefitted by unrestricted competition between railroads has been so emphatically disproved by the results which have generally followed its adoption in practice that the hope of any permanent relief from excessive rates through the competition of a parallel or rival road may, as a rule, be justly characterized as illusory and fallacious. Upon authority, lalso, arrangements and contracts between competing railroads, by which unrestrained competition is prevented, do not contravene public policy."

If, then, the construction of the Act of I 890 advanced by the majority of the court renders that act unreasonable, is it not a mistake to prefer such a construction to one which will, in entire accord with public interests, amply protect the public against extortion, and at the same time enable the railroads to pay their debts, and to render a fair return to their shareholders, who, after all, are a part of that same public whose interests the court would so jealously guard.

Philadelphia, May I, I897.

George Stuart Patterson.

1 M. \& I. R. R. v. Concord R. R., 20 Atl. $3^{83}$. 